\title{
Mechanisms underlying the antiapoptotic and anti-inflammatory effects of monotropein in hydrogen peroxide-treated osteoblasts
}

\author{
FANG-BING ZHU ${ }^{1}$, JIAN-YUE WANG ${ }^{1}$, YING-LIANG ZHANG ${ }^{1}$, YUN-GEN HU ${ }^{1}$, ZHEN-SHUANG YUE ${ }^{1}$, \\ LIN-RU ZENG ${ }^{1}$, WEN-JIE ZHENG ${ }^{1}$, QIAO HOU ${ }^{1}$, SHI-GUI YAN ${ }^{2}$ and REN-FU QUAN ${ }^{1}$ \\ ${ }^{1}$ Department of Orthopedic Surgery, Xiaoshan Traditional Chinese Medical Hospital, Hangzhou, \\ Zhejiang 311200; ${ }^{2}$ Department of Orthopedic Surgery, The Second Affiliated Hospital, \\ School of Medicine, Zhejiang University, Hangzhou, Zhejiang 310009, P.R. China
}

Received June 15, 2015; Accepted August 17, 2016

DOI: $10.3892 / \mathrm{mmr} .2016 .5908$

\begin{abstract}
Monotropein, the primary iridoid glycoside isolated from Morindacitrifolia, has been previously reported to possess potent antioxidant and antiosteoporotic properties. However, there is no direct evidence correlating the antiosteoporotic effect of monotropein with its observed antioxidant capacity, and the molecular mechanisms involved in mediating these processes remain unclear. Therefore, the aim of the present study was to investigate the protective effects of monotropein against oxidative stress in osteoblasts and the mechanisms involved in mediating this process. Osteoblast viability was evaluated using the MTT assay. The mitochondrial membrane potential and reactive oxygen species were detected by flow cytometry analyses. Western blotting and enzyme-linked immunosorbent assays were performed to detect protein expression levels. A significant reduction in osteoblast viability was observed at $24 \mathrm{~h}$ following exposure to various concentrations (100-1,000 $\mu \mathrm{M})$ of $\mathrm{H}_{2} \mathrm{O}_{2}$ compared with untreated osteoblasts. The cytotoxic effect of $\mathrm{H}_{2} \mathrm{O}_{2}$ was notably reversed when osteoblasts were pretreated with $1-10 \mu \mathrm{g} / \mathrm{ml}$ monotropein. Pretreatment with $1-10 \mu \mathrm{g} / \mathrm{ml}$ monotropein increased the mitochondrial membrane potential and reduced the generation of reactive oxygen species in osteoblasts following exposure to $\mathrm{H}_{2} \mathrm{O}_{2}$. In addition, the $\mathrm{H}_{2} \mathrm{O}_{2}$-induced increase in apoptotic markers (caspase- 3 and caspase-9) and $\mathrm{H}_{2} \mathrm{O}_{2}$-induced reduction in sirtuin 1 levels were significantly reversed following pretreatment of cells with monotropein. Furthermore, monotropein significantly reduced $\mathrm{H}_{2} \mathrm{O}_{2}$-induced stimulation of $\mathrm{NF}-\kappa \mathrm{B}$ expression, in addition to the expression of a number of proinflammatory mediators. These results indicate that monotropein suppresses apoptosis
\end{abstract}

Correspondence to: Professor Ren-Fu Quan, Department of Orthopedic Surgery, Xiaoshan Traditional Chinese Medical Hospital, 152 Yucai Road, Xiaoshan, Hangzhou, Zhejiang 311200, P.R. China

E-mail: quanrenfuwz@126.com

Key words: monotropein, osteoblasts, apoptosis, mitochondrial pathway, nuclear factor- $\kappa \mathrm{B}$ pathway and the inflammatory response in $\mathrm{H}_{2} \mathrm{O}_{2}$-induced osteoblasts through the activation of the mitochondrial apoptotic signaling

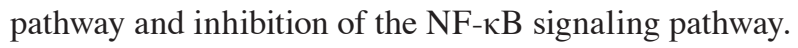

\section{Introduction}

Osteoporosis is a key public health issue that affects millions of people worldwide, and predominantly occurs in postmenopausal women $(1,2)$. It is a chronic progressive disease characterized by porous bones and the microarchitectural deterioration of bones (3). Over the last 20 years, various pharmacological agents, including alendronate, risedronate, estrogen and glucocorticoids, have been used for the prevention and treatment of osteoporosis (4-6). The primary aim of pharmacological therapy is to reduce the risk of fractures that may occur as a result of osteoporosis.

Estrogen deficiency is one of the main risk factors for osteoporosis, and has been associated with the enhanced production of reactive oxygen species (ROS) (7). Excessive levels of ROS (oxidative stress) have been demonstrated to be an important contributing factor in the etiology of various degenerative diseases, including atherosclerosis, osteoporosis and cancer, where the levels of markers associated with oxidative stress are markedly increased (8). At the cellular level, oxidant-induced injury confers a wide range of responses, including cell proliferation, differentiation arrest and apoptosis, through the activation of nuclear factor- $\kappa \mathrm{B}$ $(\mathrm{NF}-\kappa \mathrm{B}), \mathrm{p} 53$, c-Jun N-terminal kinase and extracellular signal-related kinase (ERK) signaling pathways (9). Previous studies have demonstrated that a strong correlation exists between oxidative stress and the pathogenesis of osteoporosis $(10,11)$. Oxidative stress induced by hydrogen peroxide $\left(\mathrm{H}_{2} \mathrm{O}_{2}\right)$ inhibits the differentiation of mouse MC3T3-E1 osteoblast precursor cells and M2-10B4 bone marrow cells $(12,13)$. In addition, aged osteoporotic women have been demonstrated to exhibit a marked reduction in plasma antioxidant levels (14), and a biochemical association between increased oxidative stress and reduced bone mineral density was observed in aged women and men (15). Therefore, ROS may be considered as a target for the prevention of bone density loss, and may be used as a potential candidate for the treatment of osteoporosis. 
Morindacitrifolia (M. citrifolia), also known as noni, is a tree in the Rubiaceae coffee family indigenous to the Hawaiian and Tahitian islands, and anthraquinones, flavonoids, iridoids and oligosaccharides have been isolated from M. citrifolia (16). The roots of $M$. officinalis, which are known to possess similar pharmacological effects to M. citrifolia, have been widely used in traditional Asian medicine to treat rheumatoid arthritis and diabetes (17). Monotropein is the active compound isolated from M. officinalis, and its molecular structure is shown in Fig. 1A. Previous studies demonstrated the anti-inflammatory effects of monotropein in rats with carrageenan-induced edema, in addition to in RAW 264.7 macrophages $(17,18)$. However, there is no direct evidence to correlate the antiosteoporotic effects of monotropein with its antioxidant effects, and the associated molecular mechanisms remain unclear.

In the present study, the effects of monotropein on osteoblast viability and differentiation, and the generation of ROS in osteoblasts in response to $400 \mu \mathrm{M} \mathrm{H}_{2} \mathrm{O}_{2}$ were investigated. The results demonstrated that monotropein promoted cell differentiation and protected osteoblasts from $\mathrm{H}_{2} \mathrm{O}_{2}$-induced oxidative damage by inhibiting the expression of apoptosis-associated markers and the activation of the $\mathrm{NF}-\kappa \mathrm{B}$ signaling pathway.

\section{Materials and methods}

Cell culture. The current study was approved by the Ethics Committee of the Xiaoshan Traditional Chinese Medical Hospital(Hangzhou,China). A total of 30 male Sprague-Dawley rats (age, 3 days; weight, $180 \mathrm{~g}$ ), purchased from the Experimental Animal Center of the Xiaoshan Traditional Chinese Medical Hospital (Hangzhou, China), were housed in the animal facility in individual cages at $25^{\circ} \mathrm{C}$ and $60-70 \%$ humidity with $12 \mathrm{~h}$ light/dark cycles and free access to food and water. The rats were anesthetized by intraperitoneal injection of 3\% sodium pentobarbital (40 mg/kg; Sigma-Aldrich; Merck Millipore, Darmstadt, Germany). Primary osteoblasts were prepared according to the methods described previously (19). Osteoblasts were isolated from the calvarias of newborn rats. Briefly, five calvarias were minced and incubated with $0.25 \%$ trypsin (Gibco; Thermo Fisher Scientific, Waltham, MA, USA) for $10 \mathrm{~min}$ at $37^{\circ} \mathrm{C}$, and $4 \mathrm{mg} / \mathrm{ml}$ collagenase I $(0.4 \%$; National Biochemicals Corporation, Twinsburg, OH, USA) for $90 \mathrm{~min}$ at $37^{\circ} \mathrm{C}$ three consecutive times. Cells isolated from the last four to six digests were cultured in Dulbecco's modified Eagle's medium (DMEM; Sigma-Aldrich; Merck Millipore, Darmstadt, Germany) containing $10 \%$ fetal bovine serum (FBS; Hangzhou Sijiqing Biological Engineering Materials Co., Ltd., Hangzhou, China) and antibiotics (300,000 U/1 penicillin/streptomycin; Invitrogen; Thermo Fisher Scientific, Inc.). After reaching 80-90\% confluence, the cells were removed from each flask and pooled together to produce a single osteoblast culture. Osteoblasts were subsequently collected by centrifugation $(1,000 \times \mathrm{g} / \mathrm{min}$ for $10 \mathrm{~min})$ at $4^{\circ} \mathrm{C}$ and resuspended in DMEM containing $10 \%$ FBS and 300,000 U/1 penicillin/streptomycin.

$\mathrm{H}_{2} \mathrm{O}_{2}$ treatment. Osteoblasts were harvested and randomly divided into the following 5 groups: The untreated control group; the $\mathrm{H}_{2} \mathrm{O}_{2}$-treated group; and three monotropein plus $\mathrm{H}_{2} \mathrm{O}_{2}$-treated groups, which were treated with 1,5 and $10 \mu \mathrm{g} / \mathrm{ml}$ monotropein, respectively. Osteoblasts in the $\mathrm{H}_{2} \mathrm{O}_{2}$ group were incubated for $24 \mathrm{~h}$ in DMEM containing $400 \mu \mathrm{M} \mathrm{H}_{2} \mathrm{O}_{2}$. In the monotropein plus $\mathrm{H}_{2} \mathrm{O}_{2}$-treated groups, the cells were pre-incubated with the various concentrations of monotropein for $24 \mathrm{~h}$, prior to incubation with $400 \mu \mathrm{M} \mathrm{H}_{2} \mathrm{O}_{2}$ for $24 \mathrm{~h}$.

Monotropein. Monotropein (98\% purity) was isolated from M. officinalis (Nanjing Zelang Medical Technological Co., Ltd., Nanjing, China). It was dissolved in $150 \mu \mathrm{l}$ of dimethylsulfoxide (DMSO) and diluted to the desired concentrations prior to utilization, with the final concentration of DMSO maintained below $0.5 \%$.

Cell viability assay. Osteoblast viability was evaluated using the 3-(4,5-dimethylthiazol-2-yl)-2,5-diphenyltetrazolium bromide (MTT) assay as described previously (20). In brief, cells $\left(5 \times 10^{4}\right.$ cells $\left./ \mathrm{ml}\right)$ were first seeded in 96-well culture plates and treated with or without $\mathrm{H}_{2} \mathrm{O}_{2}$, in the absence or presence of monotropein $(1,5$ or $10 \mu \mathrm{g} / \mathrm{ml})$ for 24,48 and $72 \mathrm{~h}$. Cell viability was subsequently evaluated using an MTT Cell Proliferation assay kit (cat. no. 4890-025-K; Wuhan Amyjet Scientific Co., Ltd., Wuhan, China). The absorbance was measured at $490 \mathrm{~nm}$ with an automated Bio-Rad 550 microtiter plate reader (Bio-Rad Laboratories, Inc., Hercules, CA, USA).

Analysis of alkaline phosphatase (ALP) activity. Osteoblasts $\left(1 \times 10^{4}\right.$ cells/well) were seeded and cultured in DMEM containing $10 \%$ FBS for 4 days, prior to treatment of the cells with or without $\mathrm{H}_{2} \mathrm{O}_{2}$ and in the absence or presence of monotropein $(1,5$ and $10 \mu \mathrm{g} / \mathrm{ml})$ for a further 2 days. ALP activity was measured at the end of the treatment period using p-nitrophenylphosphate as a substrate in $0.05 \mathrm{M}$ 2-amino-2-methylpropanol and $2 \mathrm{mM} \mathrm{MgCl}_{2}$ ( $\mathrm{pH} 10.5$ ), according to the methods described previously (21). The amount of p-nitrophenol released was estimated by measuring the absorbance at $410 \mathrm{~nm}$. The total protein concentration was determined using the Bradford protein assay as described previously (22).

Mitochondrial membrane potential (MMP). Rhodamine-123 dye (Sigma Aldrich; Merck Millipore) was used to measure alterations in osteoblast MMP levels. Cells $\left(1 \times 10^{4}\right.$ cells/well $)$ were seeded in a 24-well plate. Following treatment with or without $\mathrm{H}_{2} \mathrm{O}_{2}$, in the absence or presence of monotropein (1, 5 and $10 \mu \mathrm{g} / \mathrm{ml}$ ) for $24 \mathrm{~h}$, cells were washed with PBS, incubated with Rho-123 $(10 \mathrm{mg} / \mathrm{ml})$ and subsequently subjected to flow cytometry analysis using the BD Accuri C6 flow cytometer (BD Biosciences, San Jose, CA, USA; excitation wavelength, $480 \mathrm{~nm}$; emission wavelength, $525 \mathrm{~nm}$ ).

Detection of ROS. Detection of ROS was performed using flow cytometric analysis as described previously (23). In brief, osteoblasts $\left(1 \times 10^{4}\right.$ cells/well) were first seeded in a 24 -well plate. Following treatment with or without $\mathrm{H}_{2} \mathrm{O}_{2}$, in the absence or presence of monotropein $(1,5$ and $10 \mu \mathrm{g} / \mathrm{ml})$ for $24 \mathrm{~h}$, cells were washed with PBS, resuspended in complete medium and incubated with $0.5 \mu \mathrm{M}$ dihydrorhodamine 123 (Sigma Aldrich; Merck Millipore) for $30 \mathrm{~min}$ at $37^{\circ} \mathrm{C}$. ROS fluorescence intensity was determined by flow cytometric analysis, with excitation at $490 \mathrm{~nm}$ and emission at $520 \mathrm{~nm}$. 
A

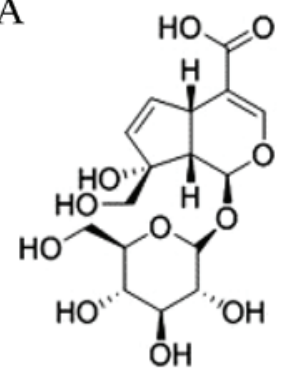

B

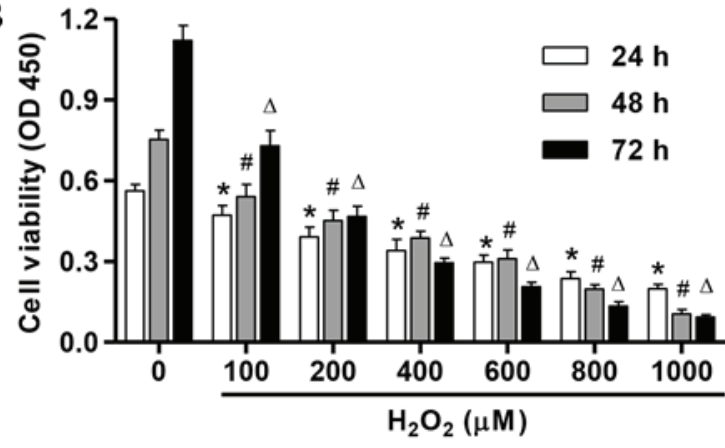

$\mathrm{C}$

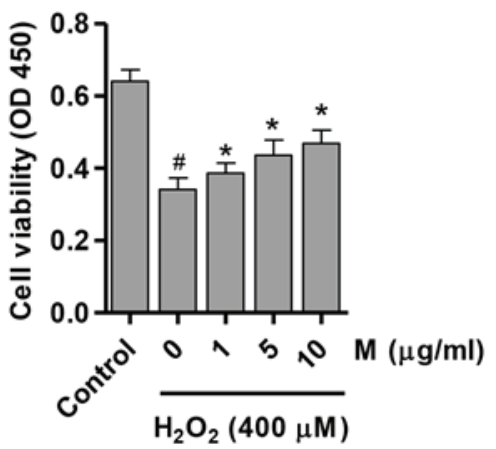

Figure 1. $\mathrm{M}$ increases the viability of $\mathrm{H}_{2} \mathrm{O}_{2}$-induced osteoblasts. (A) The chemical structure of M. The viability of osteoblasts following treatment with (B) $\mathrm{H}_{2} \mathrm{O}_{2}(0-1000 \mu \mathrm{M})$ for 24,48 and $72 \mathrm{~h}$ and $(\mathrm{C}) \mathrm{H}_{2} \mathrm{O}_{2}(400 \mu \mathrm{M})$ following pretreatment with $0,1,5 \mathrm{or} 10 \mu \mathrm{g} / \mathrm{ml} \mathrm{M}$ for $24 \mathrm{~h}$, as determined using an MTT assay. Data are presented as the mean \pm standard deviation. ${ }^{*}, \#, \Delta \mathrm{P}<0.05$ vs. untreated control group. M, monotropein; OD, optical density.

Western blot analysis. Cells were seeded at a density of $1 \times 10^{5}$ cells/well in 6-well plates, incubated overnight and then treated with or without $\mathrm{H}_{2} \mathrm{O}_{2}$ in the absence or presence of monotropein $(1,5$ and $10 \mu \mathrm{g} / \mathrm{ml})$ for $24 \mathrm{~h}$. Cells were lysed using radioimmunoprecipitation buffer supplemented with protease inhibitor (Beyotime Institute of Biotechnology, Shanghai, China). The protein concentration was estimated using a bicinchoninic acid assay kit (Thermo Fisher Scientific, Inc.). Cell protein lysates $(50 \mu \mathrm{g})$ were separated on $10 \%$ sodium dodecyl sulfate-polyacrylamide gels and electroblotted onto a polyvinylidene fluoride membrane (Roche Diagnostics $\mathrm{GmbH}$, Mannheim, Germany). Membranes were blocked in fat-free milk overnight at $4^{\circ} \mathrm{C}$. Membranes were then incubated with the following primary antibodies for $2 \mathrm{~h}$ at $25^{\circ} \mathrm{C}$ : Polyclonal rabbit anti-caspase-3 (dilution, 1:200; cat. no. ab2302; Abcam, Cambridge, MA, USA); anti-caspase-9 (dilution, 1:500; cat. no. ab69514; Abcam); anti-cyclooxygenase-2 (COX-2; dilution, 1:500; cat. no. ab15191; Abcam); anti-inducible nitric oxide synthase (iNOS; dilution, 1:800; cat. no. ab3523; Abcam); anti-NF-кB p65 (dilution, 1:1,000; cat. no. ab16502; Abcam); and monoclonal mouse anti-sirtuin 1 (SIRT1; dilution, 1:800; cat. no. ab110304; Abcam). Mouse anti-histone protein 3 (dilution, 1:1,000; cat. no. ab1220; Abcam) or anti-GAPDH (dilution, 1:1,000; cat. no. ab8245; Abcam) monoclonal antibodies were used as loading controls. After washing, the membranes were incubated with horseradish peroxidase-conjugated goat anti-rabbit (cat. no. A0208) or goat anti-mouse IgG (cat. no. A0216) secondary antibodies (dilution, 1:1,000; Beyotime Institute of Biotechnology) at $37^{\circ} \mathrm{C}$ for $1 \mathrm{~h}$. The blots were visualized using enhanced chemiluminescence (EMD Millipore, Billerica, MA, USA) and signal intensity was determined using ImageJ software (version 1.46; National Institutes of Health, Bethesda, MD, USA).

Enzyme-linked immunosorbent assay (ELISA). The protein levels of rat tumor necrosis factor-a (TNF- $\alpha$ ), interleukin (IL)-1 $\beta$, IL-6 and macrophage-colony stimulating factor (M-CSF) in osteoblasts were determined using Quantikine murine-specific sandwich ELISA kits (cat. nos. RTA00, RLB00, R6000B and MMC00, respectively; R\&D Systems, Inc., Minneapolis, MN, USA) according to the manufacturer's instructions. Absorbance was read at $570 \mathrm{~nm}$ using an EL301 Microwell Strip Reader (Omega Bio-Tek, Inc., Norcross, GA, USA).
Statistical analysis. Data are expressed as the mean \pm standard deviation. Differences between groups were analyzed using a two-tailed Student's $t$-test. The SPSS statistical software program (version, 13.0; SPSS, Inc., Chicago, IL, USA) was used for analysis. $\mathrm{P}<0.05$ was considered to indicate a statistically significant difference.

\section{Results}

Effect of monotropein on the viability of osteoblasts. To determine whether $\mathrm{H}_{2} \mathrm{O}_{2}$ may exhibit cytotoxic effects on osteoblasts in vitro, the effect of $\mathrm{H}_{2} \mathrm{O}_{2}$ exposure on osteoblast viability was determined using an MTT assay. Osteoblasts were treated with $0-1,000 \mu \mathrm{M} \mathrm{H}_{2} \mathrm{O}_{2}$ for 24,48 and $72 \mathrm{~h}$. As presented in Fig. $1 \mathrm{~B}$, treatment with $>400 \mu \mathrm{M} \mathrm{H}_{2} \mathrm{O}_{2}$ significantly reduced cell viability in a dose and time-dependent manner $(\mathrm{P}=0.001)$. Therefore, $400 \mu \mathrm{M} \mathrm{H}_{2} \mathrm{O}_{2}$ was used in all subsequent experiments. As presented in Fig. 1C, 1, 5 and $10 \mu \mathrm{g} / \mathrm{ml}$ monotropein significantly inhibited the $\mathrm{H}_{2} \mathrm{O}_{2}$-induced suppression in osteoblast viability $(\mathrm{P}=0.011 ; 13.2 \pm 1.63,27.9 \pm 2.65$ and $37.5 \pm 2.32 \%$ viability increase compared with osteoblasts treated with $\mathrm{H}_{2} \mathrm{O}_{2}$ alone, respectively).

Effect of monotropein on the differentiation of osteoblasts. ALP activation is the earliest marker of osteoblast differentiation (24). In addition, the M-CSF cytokine is constitutively expressed during the growth phase of osteoblasts (25). As presented in Fig. 2A, a significant reduction in ALP activity was observed following incubation of osteoblasts with $>200 \mu \mathrm{M}$ $\mathrm{H}_{2} \mathrm{O}_{2}(\mathrm{P}<0.05)$. Notably, pretreatment of cells with monotropein $(1,5$ and $10 \mu \mathrm{g} / \mathrm{ml})$ for $24 \mathrm{~h}$ significantly attenuated the $\mathrm{H}_{2} \mathrm{O}_{2}$-mediated downregulation of ALP activity (21.7 \pm 2.23 , $34.2 \pm 2.02$ and $45.1 \pm 1.35 \%$ activity increase, compared with osteoblasts treated with $\mathrm{H}_{2} \mathrm{O}_{2}$ alone, respectively; $1 \mu \mathrm{g} / \mathrm{ml}$, $\mathrm{P}=0.005 ; 5 \mu \mathrm{g} / \mathrm{ml}, \mathrm{P}=0.0002 ; 10 \mu \mathrm{g} / \mathrm{ml}, \mathrm{P}=1.16 \times 10^{-5}$; Fig. $2 \mathrm{~B}$ ). In addition, pretreatment with 1,5 and $10 \mu \mathrm{g} / \mathrm{ml}$ monotropein significantly increased M-CSF expression compared with $\mathrm{H}_{2} \mathrm{O}_{2}$-only treated osteoblasts $(27.1 \pm 1.83,46.7 \pm 1.52$ and $61.4 \pm 1.35 \%$, respectively; $1 \mu \mathrm{g} / \mathrm{ml}, \mathrm{P}=0.0003 ; 5 \mu \mathrm{g} / \mathrm{ml}$, $\mathrm{P}=2.78 \times 10^{-5} ; 10 \mu \mathrm{g} / \mathrm{ml}, \mathrm{P}=1.21 \times 10^{-5}$; Fig. 2C).

Effect ofmonotropein on MMP and ROSlevels in $\mathrm{H}_{2} \mathrm{O}_{2}$-induced osteoblasts. Destruction of the MMP is the initial process of 

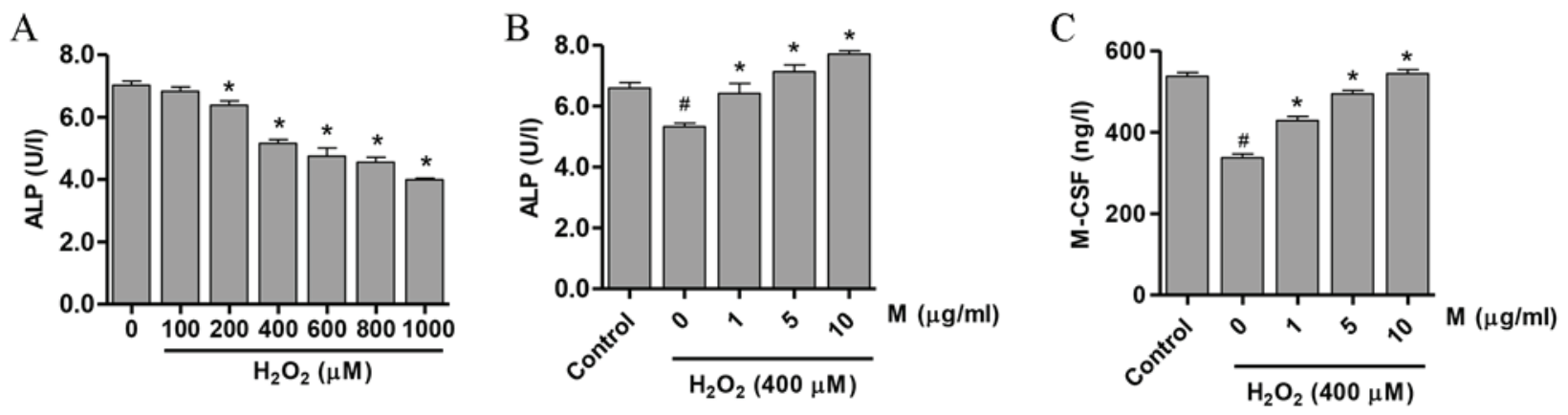

Figure 2. $\mathrm{M}$ induces the differentiation of $\mathrm{H}_{2} \mathrm{O}_{2}$-treated osteoblasts. ALP activity in osteoblasts following treatment with $(\mathrm{A}) \mathrm{H}_{2} \mathrm{O}_{2}(0-1000 \mu \mathrm{M})$ for $24 \mathrm{~h}$ demonstrating that ALP activity was reduced in a dose-dependent manner, and (B) $\mathrm{H}_{2} \mathrm{O}_{2}(400 \mu \mathrm{M})$ following pretreatment with $0,1,5$ or $10 \mu \mathrm{g} / \mathrm{ml} \mathrm{M}$ for $24 \mathrm{~h}$. (C) M-CSF expression in osteoblasts treated with $0,1,5$ or $10 \mu \mathrm{g} / \mathrm{ml} \mathrm{M}$ for $24 \mathrm{~h}$ prior to exposure to $400 \mu \mathrm{M} \mathrm{H}_{2} \mathrm{O}_{2}$. Data are presented as the mean \pm standard deviation. ${ }^{.} \mathrm{P}<0.05$, vs. control group; ${ }^{\mathrm{P}}<0.05$, vs. $0 \mu \mathrm{M}$ M group. M, monotropein; ALP, alkaline phosphatase; M-CSF, macrophage-colony stimulating factor.
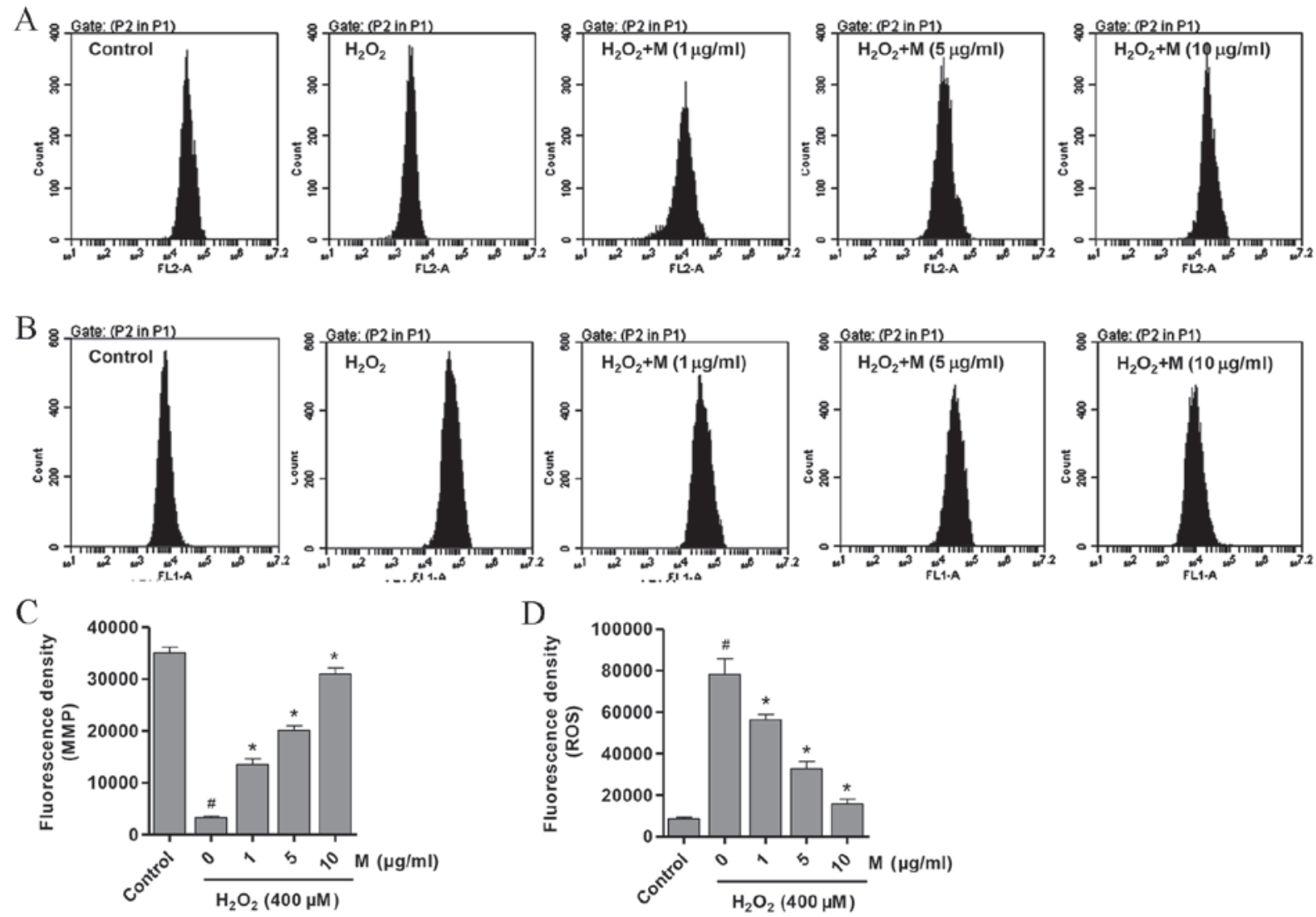

Figure 3. Effect of M on MMP and ROS production in $\mathrm{H}_{2} \mathrm{O}_{2}$-induced osteoblasts. The (A) MMP and (B) ROS levels in osteoblasts pretreated with M (0, 1 , 5 and $10 \mu \mathrm{g} / \mathrm{ml})$ for $24 \mathrm{~h}$ prior to treatment with $\mathrm{H}_{2} \mathrm{O}_{2}(400 \mu \mathrm{M})$, as determined by flow cytometry analysis. Quantitative analysis of (C) MMP and (D) ROS levels in the same samples. Data are presented as the mean \pm standard deviation. ${ }^{\prime \prime} \mathrm{P}<0.05$, vs. untreated controls; ${ }^{\mathrm{P}}<0.05$, vs. the $\mathrm{H}_{2} \mathrm{O}_{2}$ only-treated group. $\mathrm{M}$, monotropein; MMP, matrix metalloproteinase; ROS, reactive oxygen species.

mitochondrial-induced apoptosis (26). To elucidate the possible mechanisms by whichmonotropein prevented the $\mathrm{H}_{2} \mathrm{O}_{2}$-induced decrease in cell viability and ALP activity in osteoblasts, the MMP and intracellular ROS levels in $\mathrm{H}_{2} \mathrm{O}_{2}$-treated osteoblasts with or without monotropein pretreatment were investigated. The MMP level in $\mathrm{H}_{2} \mathrm{O}_{2}$-induced osteoblasts was significantly decreased compared with that of the untreated control osteoblasts (Fig. 3A and C; $\mathrm{P}=9.98 \times 10^{-7}$ ). However, osteoblasts pretreated with monotropein $(1,5$ and $10 \mu \mathrm{g} / \mathrm{ml})$ exhibited a significant dose-dependent increase in MMP levels
(Fig. 3A and C; $1 \mu \mathrm{g} / \mathrm{ml}, \mathrm{P}=9.59 \times 10^{-5} ; 5 \mu \mathrm{g} / \mathrm{ml}, \mathrm{P}=7.86 \times 10^{-6}$; $\left.10 \mu \mathrm{g} / \mathrm{ml}, \mathrm{P}=2.72 \times 10^{-6}\right)$. MMP levels were increased by 3.1, 5.1 and 8.4-fold following pretreatment with 1,5 and $10 \mu \mathrm{g} / \mathrm{ml}$ monotropein, respectively, when compared with that of $\mathrm{H}_{2} \mathrm{O}_{2}$-only treated osteoblasts. Similarly, ROS generation in monotropein-treated osteoblasts was significantly reduced in a dose-dependent manner when compared with $\mathrm{H}_{2} \mathrm{O}_{2}$-only treated controls (Fig. 3B and D; $1 \mu \mathrm{g} / \mathrm{ml}, \mathrm{P}=0.0095 ; 5 \mu \mathrm{g} / \mathrm{ml}$, $\mathrm{P}=0.0007 ; 10 \mu \mathrm{g} / \mathrm{ml}, \mathrm{P}=0.0002)$. ROS levels were reduced by $27.9 \pm 1.26,58.2 \pm 2.16$ and $79.7 \pm 1.51 \%$ following pretreatment 
with 1,5 and $10 \mu \mathrm{g} / \mathrm{ml}$ monotropein, compared with $\mathrm{H}_{2} \mathrm{O}_{2}$-only treated osteoblasts.

Effect of monotropein on the expression of apoptosis-associated proteins. In order to investigate the mechanisms underlying the anti-apoptotic effects of monotropein in $\mathrm{H}_{2} \mathrm{O}_{2}$-induced osteoblasts, the protein expression levels of apoptosis-associated molecules were determined by western blot analysis. As presented in Fig. 4, the protein expression levels of caspase-3 $\left(\mathrm{P}=7.58 \times 10^{-5}\right)$ and caspase- $9\left(\mathrm{P}=8.57 \times 10^{-6}\right)$ were significantly increased following $\mathrm{H}_{2} \mathrm{O}_{2}$ treatment for $24 \mathrm{~h}$ compared with untreated controls, whereas SIRT1 $\left(\mathrm{P}=8.14 \times 10^{-6}\right)$ protein expression was significantly reduced. However, pretreatment of osteoblasts with monotropein $(1,5$ and $10 \mu \mathrm{g} / \mathrm{ml})$ for $24 \mathrm{~h}$ significantly attenuated the $\mathrm{H}_{2} \mathrm{O}_{2}$-induced upregulation of caspase-3 $(1 \mu \mathrm{g} / \mathrm{ml}, \mathrm{P}=0.007 ; 5 \mu \mathrm{g} / \mathrm{ml}, \mathrm{P}=0.0018 ; 10 \mu \mathrm{g} / \mathrm{ml}$, $\left.\mathrm{P}=5.77 \times 10^{-5}\right)$ and caspase $-9(1 \mu \mathrm{g} / \mathrm{ml}, \mathrm{P}=0.0489 ; 5 \mu \mathrm{g} / \mathrm{ml}$, $\mathrm{P}=0.009 ; 10 \mu \mathrm{g} / \mathrm{ml}, \mathrm{P}=0.0007)$ protein expression levels and the $\mathrm{H}_{2} \mathrm{O}_{2}$-induced downregulation in SIRT1 $(1 \mu \mathrm{g} / \mathrm{ml}, \mathrm{P}=0.001$; $5 \mu \mathrm{g} / \mathrm{ml}, \mathrm{P}=0.0005 ; 10 \mu \mathrm{g} / \mathrm{ml}, \mathrm{P}=3.89 \times 10^{-5}$ ) protein expression (Fig. 4).

Effect of monotropein on NF- $\kappa B$ p 65, iNOS and COX-2 expression levels. In order to determine whether signaling pathways downstream of NF- $\mathrm{B}$ p65 were affected by monotropein treatment, the protein expression levels of NF- $\mathrm{NB}$, iNOS and COX-2 in osteoblasts following pretreatment with $0,1,5$ or $10 \mu \mathrm{g} / \mathrm{ml}$ monotropein and exposure to $\mathrm{H}_{2} \mathrm{O}_{2}$ were examined. As presented in Fig. 5A and $\mathrm{B}$, the protein expression levels of NF- $\mathrm{KB}$ p65 $\left(\mathrm{P}=1.35 \times 10^{-5}\right)$, iNOS $\left(\mathrm{P}=9.76 \times 10^{-5}\right)$ and COX-2 $\left(\mathrm{P}=7.89 \times 10^{-6}\right)$ were significantly increased in $\mathrm{H}_{2} \mathrm{O}_{2}$-induced osteoblasts compared with untreated controls. Following monotropein treatment, osteoblasts exhibited a significant reduction in the protein expression levels of $\mathrm{NF}-\kappa \mathrm{B}$ p65 $\left(1 \mu \mathrm{g} / \mathrm{ml}, \mathrm{P}=0.001 ; 5 \mu \mathrm{g} / \mathrm{ml}, \mathrm{P}=0.0002 ; 10 \mu \mathrm{g} / \mathrm{ml}, \mathrm{P}=5.53 \times 10^{-5}\right)$, iNOS $(1 \mu \mathrm{g} / \mathrm{ml}, \mathrm{P}=0.0482 ; 5 \mu \mathrm{g} / \mathrm{ml}, \mathrm{P}=0.0162 ; 10 \mu \mathrm{g} / \mathrm{ml}$, $\mathrm{P}=0.0023)$ and COX-2 (1 $\mu \mathrm{g} / \mathrm{ml}, \mathrm{P}=0.0084 ; 5 \mu \mathrm{g} / \mathrm{ml}, \mathrm{P}=0.0017$; $10 \mu \mathrm{g} / \mathrm{ml}, \mathrm{P}=0.0001)$ compared with $\mathrm{H}_{2} \mathrm{O}_{2}$-only-treated osteoblasts (Fig. 5A and B). These data suggest that $\mathrm{H}_{2} \mathrm{O}_{2}$ may induce osteoblast injury through activating $\mathrm{NF}-\kappa \mathrm{B}$ and increasing the expression of downstream signaling pathways involving iNOS and COX-2.

Effect of monotropein on the protein expression levels of pro-inflammatory mediators. In order to determine whether inflammation was induced by $\mathrm{H}_{2} \mathrm{O}_{2}$, the protein expression levels of TNF- $\alpha$, IL- $1 \beta$ and IL- 6 in osteoblasts following incubation with $\mathrm{H}_{2} \mathrm{O}_{2}$ and in the presence or absence of monotropein were determined. As presented in Fig. 5C-E, the protein expression levels of TNF- $\alpha\left(\mathrm{P}=3.59 \times 10^{-6}\right)$, IL-1 $\beta\left(\mathrm{P}=9.19 \times 10^{-6}\right)$ and IL-6 $\left(\mathrm{P}=3.73 \times 10^{-6}\right)$ were significantly increased in $\mathrm{H}_{2} \mathrm{O}_{2}$-induced osteoblasts compared with untreated controls. Following monotropein treatment, osteoblasts exhibited a significant reduction in TNF- $\alpha\left(1 \mu \mathrm{g} / \mathrm{ml}, \mathrm{P}=0.0002 ; 5 \mu \mathrm{g} / \mathrm{ml}, \mathrm{P}=4.64 \times 10^{-5} ; 10 \mathrm{mg} / \mathrm{ml}\right.$, $\left.\mathrm{P}=9.79 \times 10^{-6}\right), \mathrm{IL}-1 \beta(1 \mu \mathrm{g} / \mathrm{ml}, \mathrm{P}=0.0024 ; 5 \mu \mathrm{g} / \mathrm{ml}, \mathrm{P}=0.0002$; $\left.10 \mu \mathrm{g} / \mathrm{ml}, \mathrm{P}=4.76 \times 10^{-5}\right)$ and IL-6 $(1 \mu \mathrm{g} / \mathrm{ml}, \mathrm{P}=0.0009 ; 5 \mu \mathrm{g} / \mathrm{ml}$, $\left.\mathrm{P}=9.96 \times 10^{-5} ; 10 \mu \mathrm{g} / \mathrm{ml}, \mathrm{P}=3.48 \times 10^{-5}\right)$ protein expression levels compared with $\mathrm{H}_{2} \mathrm{O}_{2}$-only treated osteoblasts (Fig. 5C-E). These data suggest that $\mathrm{H}_{2} \mathrm{O}_{2}$ induces osteoblast injury through stimulating inflammatory responses and increasing the
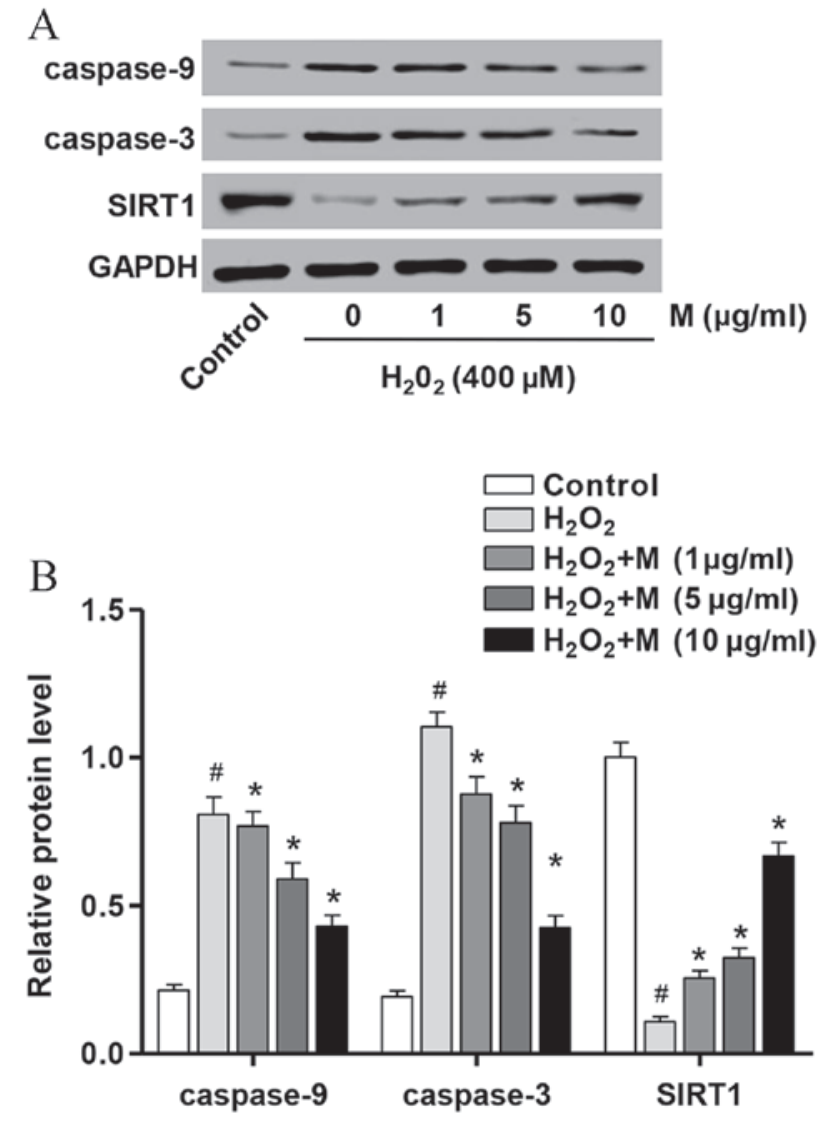

Figure 4. $\mathrm{M}$ enhances the expression of apoptosis-associated proteins in $\mathrm{H}_{2} \mathrm{O}_{2}$-induced osteoblasts. (A) Western blot analysis and (B) quantification of the protein expression levels of apoptosis-associated proteins caspase-9, caspase-3 and SIRT1 in osteoblasts pretreated with $\mathrm{M}(0,1,5$ and $10 \mu \mathrm{g} / \mathrm{ml})$ for $24 \mathrm{~h}$ prior to treatment with $\mathrm{H}_{2} \mathrm{O}_{2}(400 \mu \mathrm{M})$. Data are presented as the mean \pm standard deviation. ${ }^{\#} \mathrm{P}<0.05$, vs. untreated controls; ${ }^{*} \mathrm{P}<0.05$ vs. the $\mathrm{H}_{2} \mathrm{O}_{2}$-only treated group. M, monotropein; SIRT1, sirtuin 1; GAPDH, glyceraldehyde 3-phosphate dehydrogenase.

expression of proinflammatory mediators, including TNF- $\alpha$, IL-1 $\beta$ and IL-6.

\section{Discussion}

ROS is known to contribute to the pathogenesis of a number of diseases, such as osteoporosis (27). $\mathrm{H}_{2} \mathrm{O}_{2}$ is one of the major sources of ROS, which disperses across cell membranes and generates highly reactive hydroxyl radicals that cause various types of oxidative damage by attacking cellular components (28). $\mathrm{H}_{2} \mathrm{O}_{2}$-induced apoptosis and inflammation have been reported to occur in several types of cells including mesenchymal stem cells, cardiomyocytes and alveolar epithelial cells (29-31). In the present study, the effect of different concentrations of $\mathrm{H}_{2} \mathrm{O}_{2}$ on osteoblast viability was investigated. Treatment with $\mathrm{H}_{2} \mathrm{O}_{2}$ for 24 h significantly repressed the viability of osteoblasts at doses ranging from 100 to $1,000 \mu \mathrm{M}$ when compared with untreated controls, which indicates that $\mathrm{H}_{2} \mathrm{O}_{2}$ may inhibit the viability of osteoblasts. In a previous study, pretreatment with curculigoside, one of the main bioactive phenolic compounds isolated from the rhizome of Curculigoorchioides Gaertn, markedly protected against the $\mathrm{H}_{2} \mathrm{O}_{2}$-induced inhibition of osteoblast viability (32). Consistent with these observations, pretreatment of osteoblasts with 
A

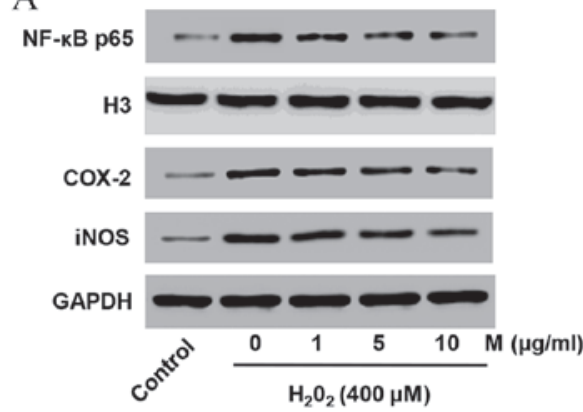

B

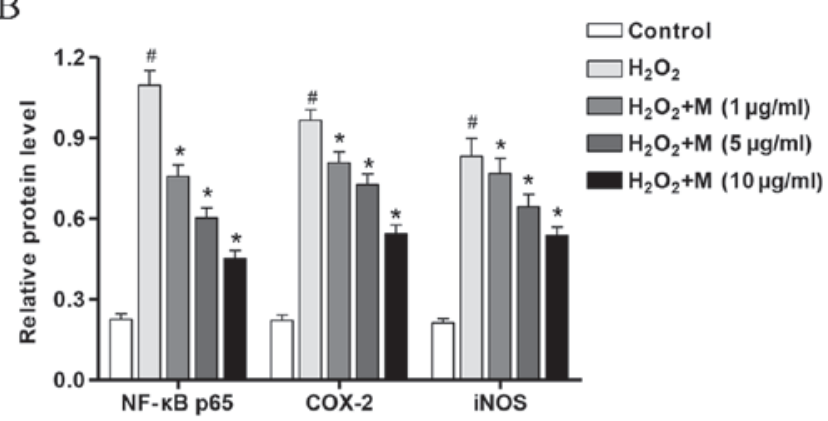

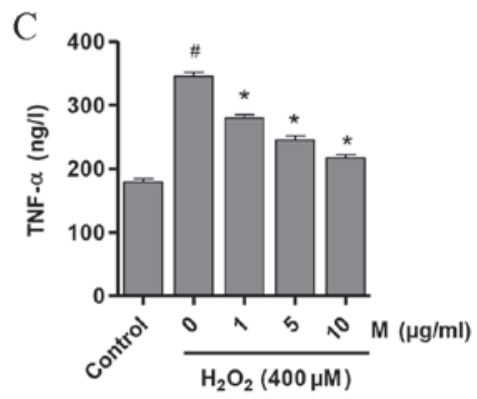
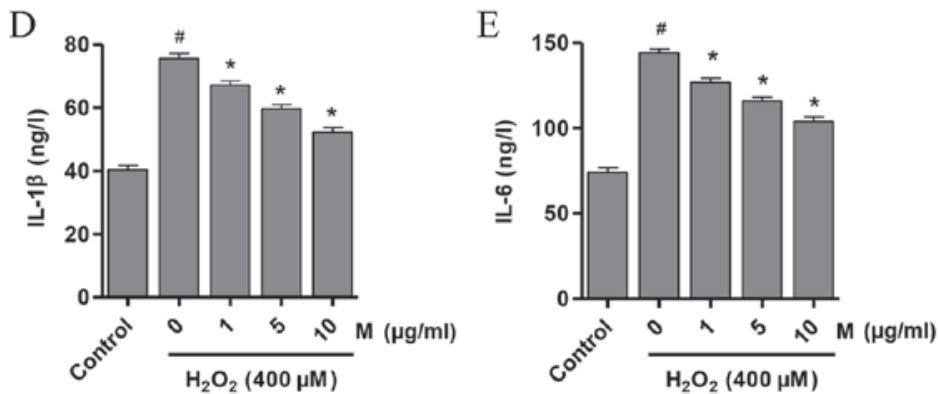

Figure 5. M suppresses the production of proinflammatory cytokines from $\mathrm{H}_{2} \mathrm{O}_{2}$-induced osteoblasts. (A) Western blot analysis and (B) quantification of the protein expression levels of NF- $\mathrm{KB}$ p65, COX-2 and iNOS in osteoblasts pretreated with $\mathrm{M}(0,1,5 \mathrm{and} 10 \mu \mathrm{g} / \mathrm{ml})$ for $24 \mathrm{~h}$ prior to treatment with $\mathrm{H}_{2} \mathrm{O}_{2}$ $(400 \mu \mathrm{M})$ Quantification of (C) TNF- $\alpha$, (D) IL-1 $\beta$ and (E) IL-6 protein expression levels in the same samples as determined by enzyme-linked immunosorbent assay. Data are presented as the mean \pm standard deviation. ${ }^{~} \mathrm{P}<0.05$ vs. untreated controls; ${ }^{*} \mathrm{P}<0.05$ vs. the $\mathrm{H}_{2} \mathrm{O}_{2}$ only-treated group. M, monotropein; NF-кB p65, nuclear factorkB p65; COX-2, cyclooxygenase 2; iNOS, inducible nitric oxide synthase; TNF- $\alpha$, tumor necrosis factor $\alpha$; IL, interleukin; ELISA, enzyme-linked immunosorbent assay.

$1-10 \mu \mathrm{g} / \mathrm{ml}$ monotropein for $24 \mathrm{~h}$ in the present study, significantly suppressed cell injury following exposure to $400 \mu \mathrm{M}$ $\mathrm{H}_{2} \mathrm{O}_{2}$. Taking these results into account, $400 \mu \mathrm{M} \mathrm{H}_{2} \mathrm{O}_{2}$ was considered to be sufficient for the induction of oxidative stress, and $1-10 \mu \mathrm{g} / \mathrm{ml}$ monotropein was selected to examine the effects of monotropein on osteoblast function.

ALP is widely expressed in various organs, including the liver, kidney, placenta and bone $(33,34)$. ALP serves an important role in bone formation and remodeling through promoting mineralization of the matrix (35). Previous studies observed $\mathrm{H}_{2} \mathrm{O}_{2}$-induced suppression of osteoblast differentiation in bone marrow stem cells and MC3T3-E1 cells $(36,37)$. M-CSF, also known as CSF1, is released by osteoblasts and is involved in the proliferation, differentiation and survival of bone marrow progenitor cells $(38,39)$. In the present study, ALP activity and M-CSF release was observed to be significantly suppressed in $\mathrm{H}_{2} \mathrm{O}_{2}$-induced osteoblasts; the levels of which recovered following monotropein treatment. These observations suggest that monotropein may promote osteoblast differentiation.

Previous studies have demonstrated that activation of ERK is important for $\mathrm{H}_{2} \mathrm{O}_{2}$-induced apoptosis in cardiomyocytes, endothelial cells and osteoblasts (40-42). $\mathrm{H}_{2} \mathrm{O}_{2}$ treatment increased Bax expression and led to hyperpolarization of the mitochondrial membrane potential in MC3T3-E1 mouse osteoblastic cells (33). This effect was prevented by treating cells with an inhibitor of the ERK upstream kinase mitogen activated protein kinase kinase1/2 (PD98059) (43). Consistent with these observations, the results presented in the current study demonstrated that monotropein could significantly reverse the $\mathrm{H}_{2} \mathrm{O}_{2}$-induced reduction in MMP levels and the
$\mathrm{H}_{2} \mathrm{O}_{2}$-induced increase in ROS production. In addition, the protein expression levels of apoptotic markers in $\mathrm{H}_{2} \mathrm{O}_{2}$-induced osteoblasts were investigated, and the results suggested that the proapoptotic genes, caspase- 3 and caspase- 9 , were significantly increased and the anti-apoptotic gene SIRT1 was significantly reduced. Notably, treatment with monotropein significantly reversed the effects of $\mathrm{H}_{2} \mathrm{O}_{2}$ on the expression of apoptosis-associated proteins in osteoblasts.

NF- $\kappa \mathrm{B}$ has been demonstrated to participate in the regulation of cell survival genes, and mediate the expression of proinflammatory cytokines, including COX-2, iNOS, TNF- $\alpha$, IL-1 $\beta$ and IL-6 $(44,45)$. In the present study, the protein expression level of nuclear NF- $\mathrm{kB}$ p65 was examined, in order to determine the activity of NF- $\mathrm{KB}$. The results demonstrated that the protein expression levels of nuclear NF- $\mathrm{kB}$ p $65, \mathrm{COX}-2$, iNOS, TNF- $\alpha$, IL-1 $\beta$ and IL- 6 were significantly increased in $\mathrm{H}_{2} \mathrm{O}_{2}$-induced osteoblasts. In addition, the expression of these proinflammatory factors was attenuated by pretreatment of cells with monotropein, which suggests that monotropein presents a possible approach for the treatment of various inflammatory diseases.

In conclusion, the results of the present study demonstrate that monotropein suppresses the functional impairment of osteoblasts as a result of $\mathrm{H}_{2} \mathrm{O}_{2}$-induced oxidative stress, and its antioxidant properties may be responsible for these antioxidative effects. Furthermore, the observations of the present study indicate that the protective effects of monotropein may be mediated by the inhibition of apoptosis-associated markers and the activation of the NF- $\kappa B$ pathway. These results provide a novel insight into the protective effects of monotropein in osteoblasts via reducing ROS generation, and suggest that 
monotropein may be a potential therapeutic agent for the treatment of osteoporosis.

\section{Acknowledgements}

This study was funded by Xiaoshan Science and Technology Bureau Funds (grant no. 2013304).

\section{References}

1. Reginster JY and Burlet N: Osteoporosis: A still increasing prevalence. Bone 38 (2 Suppl 1): S4-S9, 2006.

2. Landfeldt E, Ström O, Robbins S and Borgström F: Adherence to treatment of primary osteoporosis and its association to fractures-the Swedish Adherence Register Analysis (SARA). Osteoporosis Int 23: 433-443, 2012.

3. Burghardt AJ, Kazakia GJ, Sode M, de Papp AE, Link TM and Majumdar S: A longitudinal HR-pQCT study of alendronate treatment in postmenopausal women with low bone density: Relations among density, cortical and trabecular microarchitecture, biomechanics and bone turnover. J Bone Miner Res 25 2558-2571, 2010.

4. Kothawala P, Badamgarav E, Ryu S, Miller RM and Halbert RJ: Systematic review and meta-analysis of real-world adherence to drug therapy for osteoporosis. Mayo Clin Proc 82: 1493-1501, 2007.

5. Cramer J, Gold D, Silverman S and Lewiecki E: A systematic review of persistence and compliance with bisphosphonates for osteoporosis. Osteoporosis Int 18: 1023-1031, 2007.

6. Siris ES, Harris ST, Rosen CJ, Barr CE, Arvesen JN, Abbott TA and Silverman S: Adherence to bisphosphonate therapy and fracture rates in osteoporotic women: Relationship to vertebral and nonvertebral fractures from 2 US claims databases. Mayo Clin Proc 81: 1013-1022, 2006.

7. Lean JM, Jagger CJ, Kirstein B, Fuller K and Chambers TJ: Hydrogen peroxide is essential for estrogen-deficiency bone loss and osteoclast formation. Endocrinology 146: 728-735, 2005

8. Cencioni C, Spallotta F, Martelli F, Valente S, Mai A, Zeiher AM and Gaetano C: Oxidative stress and epigenetic regulation in ageing and age-related diseases. Int JMol Sci 14: 17643-17663, 2013.

9. Martindale JL and Holbrook NJ: Cellular response to oxidative stress: Signaling for suicide and survival. J Cell Physiol 192: $1-15,2002$.

10. Manolagas SC: From estrogen-centric to aging and oxidative stress: A revised perspective of the pathogenesis of osteoporosis. Endocr Rev 31: 266-300, 2010.

11. Sánchez-Rodríguez MA, Ruiz-Ramos M, Correa-Muñoz E and Mendoza-Núñez VM: Oxidative stress as a risk factor for osteoporosis in elderly Mexicans as characterized by antioxidant enzymes. BMC Musculoskelet Disord 8: 124, 2007.

12. Mody N, Parhami F, Sarafian TA and Demer LL: Oxidative stress modulates osteoblastic differentiation of vascular and bone cells. Free Radical Biol Med 31: 509-519, 2001.

13. Lee DH, Lim BS, Lee YK and Yang HC: Effects of hydrogen peroxide $(\mathrm{H} 2 \mathrm{O} 2)$ on alkaline phosphatase activity and matrix mineralization of odontoblast and osteoblast cell lines. Cell Biol Toxicol 22: 39-46, 2006.

14. Maggio D, Barabani M, Pierandrei M, Polidori MC, Catani M, Mecocci P, Senin U, Pacifici R and Cherubini A: Marked decrease in plasma antioxidants in aged osteoporotic women: Results of a cross-sectional study. J Clin Endocri Metab 88 1523-1527, 2003.

15. Lee YJ, Hong JY, Kim SC, Joo JK, Na YJ and Lee KS: The association between oxidative stress and bone mineral density according to menopausal status of Korean women. Obstet Gyn Sci 58: 46-52, 2015

16. Ho CT and Zheng QY: Quality management of nutraceuticals. Am Chem Soc 803, 2002.

17. Choi J, Lee K, Choi MY, Nam JH, Jung HJ, Park SK and Park HJ: Antinociceptive anti-inflammatory effect of monotropein isolated from the root of Morinda officinalis. Biol Pharm Bull 28 : 1915-1918, 2005

18. Shin JS, Yun KJ, Chung KS, Seo KH, Park HJ, Cho YW, Baek NI, Jang D and Lee KT: Monotropein isolated from the roots of Morinda officinalis ameliorates proinflammatory mediators in RAW 264.7 macrophages and dextran sulfate sodium (DSS)-induced colitis via NF- $\kappa \mathrm{B}$ inactivation. Food Chem Toxicol 53: 263-271, 2013.
19. Ishizuya T, Yokose S, Hori M, Noda T, Suda T, Yoshiki S and Yamaguchi A: Parathyroid hormone exerts disparate effects on osteoblast differentiation depending on exposure time in rat osteoblastic cells. J Clin Invest 99: 2961-2970, 1997.

20. Wang YK, Hong YJ, Wei M, Wu Y, Huang ZQ, Chen RZ and Chen HZ: Curculigoside attenuates human umbilical vein endothelial cell injury induced by $\mathrm{H} 2 \mathrm{O} 2$. J Ethnopharmacol 132: 233-239, 2010.

21. Owen TA, Aronow M, Shalhoub V, Barone LM, Wilming L, Tassinari MS, Kennedy MB, Pockwinse S, Lian JB and Stein GS: Progressive development of the rat osteoblast phenotype in vitro: Reciprocal relationships in expression of genes associated with osteoblast proliferation and differentiation during formation of the bone extracellular matrix. J Cell Physiol 143: 420-430, 1990.

22. Bradford MM: A rapid and sensitive method for the quantitation of microgram quantities of protein utilizing the principle of protein-dye binding. Anal Biochem 72: 248-254, 1976.

23. Amer J, Goldfarb A and Fibach E: Flow cytometric measurement of reactive oxygen species production by normal and thalassaemic red blood cells. Eur J Haematol 70: 84-90, 2003.

24. Horii A, Wang X, Gelain F and Zhang S: Biological designer self-assembling peptide nanofiber scaffolds significantly enhance osteoblast proliferation, differentiation and 3-D migration. PLoS One 2: e190, 2007

25. Mancino AT, Klimberg VS, Yamamoto M, Manolagas SC and Abe E: Breast cancer increases osteoclastogenesis by secreting M-CSF and upregulating RANKL in stromal cells. J Surg Res 100: 18-24, 2001.

26. Ly JD, Grubb DR and Lawen A: The mitochondrial membrane potential (deltapsi(m)) in apoptosis; an update. Apoptosis 8: $115-128,2003$.

27. Finkel T and Holbrook NJ: Oxidants, oxidative stress and the biology of ageing. Nature 408: 239-247, 2000.

28. Cabiscol E, Tamarit J and Ros J: Oxidative stress in bacteria and protein damage by reactive oxygen species. Int Microbiol 3: 3-8, 2000.

29. Cremers NA, Lundvig D, van Dalen S, Schelbergen RF, van Lent PL, Szarek WA, Regan RF, Carels CE and Wagener FA: Curcumin-induced heme oxygenase- 1 expression prevents $\mathrm{H} 2 \mathrm{O} 2$-induced cell death in wild type and heme oxygenase-2 knockout adipose-derived mesenchymal stem cells. Int J Mol Sci 15: 17974-17999, 2014.

30. Li K, Yang B and Zhao C: Transforming growth factor- $\beta$-activated kinase 1 enhances $\mathrm{H} 2 \mathrm{O} 2$-induced apoptosis independently of reactive oxygen species in cardiomyocytes. J Cardiovasc Med (Hagerstown) 15: 565-571, 2014.

31. Wei L, Yamaguchi H, Takeuchi R, Matsumoto H and Shibutani K: Propofol reduces hydrogen peroxide-induced apoptosis through down-regulating bim expression in alveolar epithelial cells. Int $\mathbf{J}$ Oral Med Sci 11: 274-279, 2013.

32. Wang Y, Zhao L, Wang Y, Xu J, Nie Y, Guo Y, Tong Y, Qin L and Zhang Q: Curculigoside isolated from Curculigo orchioides prevents hydrogen peroxide-induced dysfunction and oxidative damage in calvarial osteoblasts. Acta Bioch Bioph Sin (Shanghai) 44: 431-441, 2012.

33. Đokić-Lišanin M, Pantović V, Jovanović Z, Samardžić G and Jurišić V: Values of alkaline phosphathase and their isoenzyme profiles in patients with cancer in respect to bone and liver metastasis. Arch Oncol 21: 14-16, 2013.

34. Peters E, Heemskerk S, Masereeuw R and Pickkers P: Alkaline phosphatase: A possible treatment for sepsis-associated acute kidney injury in critically ill patients. Am J Kidney Dis 63: 1038-1048, 2014

35. Sargeant TD, Aparicio C, Goldberger JE, Cui H and Stupp SI: Mineralization of peptide amphiphile nanofibers and its effect on the differentiation of human mesenchymal stem cells. Acta Biomater 8: 2456-2465, 2012.

36. Zhou L, Chen X, Liu T, Gong Y, Chen S, Pan G, Cui W, Luo ZP, Pei M, Yang $\mathrm{H}$ and He F: Melatonin reverses $\mathrm{H} 2 \mathrm{O} 2$-induced premature senescence in mesenchymal stem cells via the SIRT1-dependent pathway. J Pineal Res 59: 190-205, 2015.

37. Fu C, Xu D, Wang CY, Jin Y, Liu Q, Meng Q, Liu KX, Sun HJ and Liu MZ: Alpha-lipoic acid promotes osteoblastic formation in H2O2-treated MC3T3-E1 cells and prevents bone loss in ovariectomized rats. J Cell Physiol 230: 2184-2201, 2015.

38. Hume DA and MacDonald KP: Therapeutic applications of macrophage Colony-Stimulating Factor-1 (CSF-1) and antagonists of CSF-1 receptor (CSF-1R) signaling. Blood 119: $1810-1820,2012$ 
39. Gow DJ, Garceau V, Kapetanovic R, Sester DP, Fici GJ, Shelly JA, Wilson TL and Hume DA: Cloning and expression of porcine Colony Stimulating Factor-1 (CSF-1) and Colony Stimulating Factor-1 Receptor (CSF-1R) and analysis of the species specificity of stimulation by CSF-1 and Interleukin 34. Cytokine 60: 793-805, 2012.

40. Sun B, Sun GB, Xiao J, Chen RC, Wang X, Wu Y, Cao L, Yang ZH and Sun XB: Isorhamnetin inhibits $\mathrm{H}_{2} \mathrm{O}_{2}$-induced activation of the intrinsic apoptotic pathway in $\mathrm{H} 9 \mathrm{c} 2$ cardiomyocytes through scavenging reactive oxygen species and ERK inactivation. J Cel Biochem 113: 473-485, 2012.

41. Polidoro L, Properzi G, Marampon F, Gravina GL, Festuccia C, Di Cesare E, Scarsella L, Ciccarelli C, Zani BM and Ferri C: Vitamin D protects human endothelial cells from $\mathrm{H} 2 \mathrm{O} 2$ oxidant injury through the Mek/Erk-Sirt1 axis activation. J Cardiovasc Transl Res 6: 221-231, 2013.
42. Liang D, Yang M, Guo B, Cao J, Yang L, Guo X, Li Y and Gao Z: Zinc inhibits $\mathrm{H}(2) \mathrm{O}(2)$-induced MC3T3-E1 cells apoptosis via MAPK and PI3K/AKT pathways. BiolTrace Elem Res 148: 420-429, 2012.

43. Park BG, Yoo CI, Kim HT, Kwon CH and Kim YK: Role of mitogen-activated protein kinases in hydrogen peroxide-induced cell death in osteoblastic cells. Toxicology 215: 115-125, 2005.

44. Peng C, Perera PK, Li YM, Fang WR, Liu LF and Li FW: Anti-inflammatory effects of Clematis chinensis Osbeck extract(AR-6) may be associated with NF- $\mathrm{BB}, \mathrm{TNF}-\alpha$ and COX-2 in collagen-induced arthritis in rat. Rheumatol Int 32: 3119-3125, 2012.

45. Li M, Zhang L, Cai RL, Gao Y and Qi Y: Lipid-soluble extracts from Salvia miltiorrhiza inhibit production of LPS-induced inflammatory mediators via NF- $\kappa \mathrm{B}$ modulation in RAW 264.7 cells and perform antiinflammatory effects in vivo. Phytother Res 26: 1195-1204, 2012. 